ББК 63.4

$$
\begin{gathered}
\text { Организация конференции и издание материалов проведены } \\
\text { при финансовой поддержке Российского фонда фундаментальных исследований, } \\
\text { проект № 19-09-20008 }
\end{gathered}
$$

Утверждено к печати Ученым советом ИИМК РАН

Редакционная коллегия тома II: А. В. Поляков, Е. С. Ткач (отв. редакторы), М. Т. Кашуба, Л. Б. Кирчо, Е. А. Черлёнок, В. Я. Стёганцева, А. И. Климушина

Рещензенты: д. и. н. Л. Б. Вишняцкий, д. и. н. А. А. Выборнов

Программный комитет конференции: академик РАН, д. и. н., проф. М. Б. Пиотровский (Государственный Эрмитаж, почетный председатель); д. и. н. В. А. Лапшин (ИИМК РАН, председатель); д. и. н. А. В. Головнёв (МАЭ РАН, сопредседатель); д. и. н. В. А. Дергачёв (Высшая антропологическая школа, Молдова, сопредседатель); д. и. н. И. Ф. Попова (ИВР РАН, сопредседатель); академик АН Республики Узбекистан, д. и. н., проф. Э. В. Ртвеладзе (сопредседатель); к. и. н. А. В. Поляков (ИИМК РАН, зам. председателя); к. и. н. В. А. Алёкшин (ИИМК РАН, зам. председателя); д. и. н. Ю. Е. Берёзкин (МАЭ РАН); Dr., Prof. Н. Бороффка

(Германский археологический институт, Германия); В. С. Бочкарёв (ИИМК РАН);

Dr. Э. Кайзер (Свободный университет Берлина, Германия); к. и. н. М. Т. Кашуба (ИИМК РАН); д. и. н. Л. Б. Кирчо (ИИМК РАН); к. и. н. А. В. Кияшко (Южный федеральный университет); к. и. н. П. Ф. Кузнецов (СГСПУ); к. и. н. Н. М. Малов (СНИГУ); к. и. н. В. П. Никоноров (ИИМК РАН); Ю. Ю. Пиотровский (Государственный Эрмитаж); д. и. н., проф. Д. Г. Савинов (Институт истории СПбГУ); к. и. н. В. Н. Седых (Институт истории СПбГУ); к. и. н. Н. Н. Скакун (ИИМК РАН); к. и. н. Н. Ф. Соловьёва (ИИМК РАН); к. и. н. А. И. Торгоев (Государственный Эрмитаж); к. и. н. Е. А. Черлёнок (Институт истории СПбГУ)

Организационный комитет конференции: к. и. н. А. В. Поляков (ИИМК РАН, председатель); к. и. н. В. А. Алёкшин (ИИМК РАН, зам. председателя); В. С. Бочкарёв (ИИМК РАН); к. и. н. М. Т. Кашуба (ИИМК РАН); д. и. н. Л. Б. Кирчо (ИИМК РАН);

А. И. Климушина (ИИМК РАН, отв. секретарь); к. и. н. В. П. Никоноров (ИИМК РАН); Ю. Ю. Пиотровский (Государственный Эрмитаж); В. Я. Стеганцева (ИИМК РАН); В. В. Терёхина (ИИМК РАН, МАЭ РАН, отв. секретарь); к. и. н. Е. С. Ткач (ИИМК РАН); И. Ж. Тутаева (Государственный Эрмитаж); к. и. н. Е. А. Черлёнок (Институт истории СПбГУ)

Древности Восточной Европы, Центральной Азии и Южной Сибири в контексте связей и взаимодействий в евразийском культурном пространстве (новые данные и концепции): Материалы Международной конференции, 18-22 ноября 2019 г., Санкт-Петербург. Т. ІІ. Связи, контакты и взаимодействия древних культур Северной Евразии и цивилизаций Востока в эпоху палеометалла (IV-I тыс. до н. э.). К 80-летию со дня рождения выдающегося археолога В. С. Бочкарёва. - СПб.: ИИМК РАН, Невская Типография, 2019. - 287 с.

ISBN 978-5-907053-35-9

DOI 10.31600/978-5-907053-35-9 
Свидетельство Регистрационной палаты мэрии Санкт-Петербурга № 5235 о государственной регистрации государственного учреждения «Институт истории материальной культуры Российской академии наук» Устав ИИМК РАН. 17.05.1994 г. // НА ИИМК РАН. РО. Ф. 312. Оп. 1. Д. № 1734.

Устав Института истории материальной культуры Российской академии наук (ИИМК РАН) 22.04.-01.06.1998 г. // НА ИИМК РАН. РО. Ф. 312. Оп. 1. Д. 1826.

\title{
THE CONTRIBUTION BY V. M. MASSON AND V. S. BOCHKAREV INTO THE PROGRESS OF RUSSIAN CULTURAL GENETIC STUDIES OF EURASIAN PEOPLES OF THE PALEOMETALLIC EPOCH
}

\author{
Alexey V. Bondarev, Lubov' M. Mosolova \\ The Herzen State Pedagogical University, St. Petersburg, Russia
}

Keywords: Vadim Mikhaylovich Masson, Vadim Sergeyevich Bochkarev, historical culturology, culturogenesis, cultural heritage, culturogenetic studies, history of culture, Eurasia.

This report is devoted to the scientific contribution by V. M. Masson and V. S. Bochkarev into the development of Russian culturogenetic studies of Eurasian peoples in the Paleometallic Epoch. The paper is timed to three significant dates marking the year of 2019: the $80^{\text {th }}$ anniversary of Vadim S. Bochkarev, one of the leading researchers of the Bronze Age of Northern Eurasia; the $90^{\text {th }}$ anniversary of the prominent national archaeologist Vadim M. Masson, expert in the history and culture of early civilizations; and the $100^{\text {th }}$ anniversary of the foundation of the Institute for the History of Material Culture RAS which is the heart of the culturogenetic studies in our country. The importance of works by V. M. Masson and V. S. Bochkarev for historical culturology is here demonstrated. The two scientists, through their discoveries, considerably expanded and deepened our notions on the cultural heritage of peoples of Eurasia from the Volga to the Sayan-Altai and from the Urals to South Turkmenia. They not only discovered and depicted the unique archaeological materials of steppe nomads and early agriculturalists of the South, but also developed confident historical and culturological interpretations of a typological character for the life activities of the creators of the artifacts found by the researchers. They have filled many lacunas in the understanding of the peculiarities of the cultural genesis and cultural heritage of Eurasian peoples in the abovementioned area from the Bronze Age until the early Middle Ages.

\section{«ГЕНЕТИЧЕСКАЯ РЕВОЛЮЦИЯ» В СВЕТЕ АКТУАЛЬНЫХ ПРОБЛЕМ ИСТОРИИ СЕВЕРНОЙ ЕВРАЗИИ В ЭПОХУ ПАЛЕОМЕТАЛЛА ${ }^{1}$}

\author{
В. А. Новожёнов \\ Центр сближения культур при ЮНЕСКО, Алма-ата, Казахстан
}

DOI: 10.31600/978-5-907053-35-9-12-15

Ключевые слова: миграция, евразийские степи, ямная, катакомбная общности, чемурчекская миграция, доместикаиия лошади, ботайская культура, синташтинская культура, эпоха палеометалла.

Из множества проблем, связанных с изучением самых ранних периодов в истории Северной Евразии, есть две ключевые: миграция западноевразийских скотоводов на восток континента и первые эксперименты по доместикации лошади. Конфронтационная модель постоянного противостояния между кочевым миром «варваров» и древнейшими оседлыми социумами долгое время оставалась единственной объяснительной концепцией взаимодействия народов в Центральной Азии.

\footnotetext{
${ }^{1}$ Работа выполнена в рамках проекта Министерства образования и науки Республики Казахстан АР05131564: «Разработка модели коммуникаций в Центральной Азии: влияние традиций и диалог культур».
} 
В последние годы новые исследования привели к решительному пересмотру этого подхода, что связано с «генетической революцией» - данные популяционной генетики позволяют выявить миграции некоторых отдельных кланов, потенциальных носителей инноваций (Allentoft et al. 2015; Damgaard et al. 2018a; 2018b; Goldberg 2017; Haak et al. 2015; Klejn et al. 2017; Kristiansen et al. 2018; Lazaridis, Reich 2017), а также отслеживать распространение патогенных вирусов: гепатита B, бубонной чумы (Mühlemann et al. 2018). Однако этот инструмент не идеален. Только в сочетании с традиционными методами можно реконструировать конкретные исторические процессы.

На основании археологических, изобразительных и лингвистических источников некоторые исследователи начиная с конца прошлого столетия предполагали миграцию части западной степной популяции животноводов на восток, и определяли ее как ямную (прототохарскую) (Шер 1980: 215; Семёнов 1987; Подольский 2007: 128; Новожёнов 2014) или как чемурчекскую (Ковалёв 2012). Энеолит и ранний бронзовый век в Казахской степи, на ее северных и восточных границах, представлены памятниками достаточно разнообразных культурных типов (Мерц, Святко 2016: 128), притом что антропологический облик населения исключительно европеоидный, на который накладывались различные западные субстраты (Хохлов, Китов 2015: 437-445; Козинцев 2009).

Особый интерес представляют новые данные о генетике древних видов лошадей и их доместикации в Казахской степи (Gaunitz et al. 2018; Outram 2014). Ботайские лошади происходят от лошади Пржевальского и генетически отличаются от других пород вида equus cabalus. Дикая лошадь Пржевальского была, по-видимому, частично одомашнена ботайцами и активно использовалась в хозяйственной деятельности, включая очевидные попытки запрячь ее в колесницу. В результате новых волн миграции из других регионов появляются лошади, которые, вероятно, ведут свою родословную от тарпанов.

Так, новая, более поздняя, волна, отразилась в генотипе носителей синташтинской культуры, также подтверждая генетическую близость этого населения с кланами из западных областей степной Евразии, что можно объяснить как их миграцией из западных областей, так и общим родством с их более ранними ямными (катакомбными) родственниками «первой волны миграции», успешно развивавшимися на новых территориях самостоятельно и смешиваясь с аборигенным населением. Популяционная генетика не подтверждает родство синташтинцев с какими-либо группами населения из Анатолии или других регионов Азии, что четко указывает на их западное, степное происхождение и не подтверждает их миграцию из Анатолии (Григорьев 2012: 40-48).

В целом не только активное использование лошадей, но и крупного рогатого скота, овец, коз и даже собак ближневосточных пород становится характерной чертой животноводческого сектора экономики населения Центральной Азии (Ollivier et al. 2018; Daly Kevin et al. 2018). Группы животноводов, мигрировавших с запада, включают местное автохтонное население в орбиту своего влияния. В то же время занятие животноводством успешно сочеталось с земледелием в тех местах, где это было возможно (Doumani et al. 2015; Motuzaite Matuzeviciute et al. 2012; 2016). Позднее, с появлением нового родственного западного компонента, формируются новые волны трансконтинентальных миграций, фиксируется глобальное «движение» металла и олова в степи (Черных 2009), появляются комплексы смешанного культурного типа.

\section{Литература}

Григорьев С. А. 2012. Миграции и их роль в культурогенезе Евразии // Культуры степной Евразии и их взаимодействие с древними цивилизациями: ММНК, посвящ. 110-летию со дня рождения выдающегося российского археолога М. П. Грязнова. СПб. Т. 2. С. 40-49. 
Ковалёв А. А. 2012. Древнейшие европейцы в сердце Азии: чемурчекский феномен как ключ к решению проблемы тохарской прародины // Там же. С. 49-57.

Козинцев А. Г. 2009. О ранних миграциях европеоидов в Сибирь и Центральную Азию (в связи с индоевропейской проблемой) // АЭАЕ. № 4 (40). С. 125-136.

Мерц И. В., Святко С. В. 2016. Радиоуглеродная хронология памятников раннего бронзового века Северо-Восточного и Восточного Казахстана. Первый опыт // Теория и практика археологических исследований. № 1(13). С. 126-149.

Новожёнов В. А. 2014. Великая степь: человек в системе древних коммуникаций // Епимахов А. В. (ред.). Таинство этнической истории древнейших номадов степной Евразии. Алматы. С. $17-265$.

Подольский М. Л. 2007. Феномен и парадоксы Минусинской степи (изменение культурных доминант) // Культурные и экологические ареалы: взаимодействие традиций и культурогенез. СПб. С. 113-128.

Семёнов В. А. 1987. Древнеямная культура - афанасьевская культура и проблема прототохарской миграции на восток // Смены культур и миграции в Западной Сибири. Томск. С. 17-19.

Хохлов А. А., Китов Е. П. 2015. Физический облик представителей ботайской энеолитической культуры в контексте проблемы формирования степного населения Казахстана // Казахское ханство в потоке истории. Алматы. С. 437-445.

Черных Е. Н. 2009. Степной пояс Евразии: Феномен кочевых культур. М.

Шер Я. А. 1980. Петроглифы Средней и Центральной Азии. М.

Allentoft M. E. et al. 2015. Population genomics of Bronze Age Eurasia. In: Nature. No. 522 (7555). P. 167-172.

Daly Kevin G. et al. 2018. Ancient goat genomes reveal mosaic domestication in the Fertile Crescent. In: Science. No. 361 (6397). P. 85-88.

Damgaard P. et al. 2018a. The first horse herders and the impact of early Bronze Age steppe expansions into Asia. In: Science. No. 556, 09 May. P. 1-34.

Damgaard P. et al. 2018b. 137 ancient human genomes from across the Eurasian steppe. In: Nature. No. 557 (7705), 17 may. P. 369-374.

Doumani P. N. et al. 2015. Burial ritual, agriculture, and craft production among Bronze Age pastoralists at Tasbas (Kazakhstan). In: Archaeological Research in Asia. No. 1-2. P. 17-32.

Gaunitz Ch. et al. 2018. Ancient genomes revisit the ancestry of domestic and Przewalski's horses. In: Science. No. 22, Feb. 2018. P. 111-114.

Goldberg A. et al. 2017. Ancient X chromosomes reveal contrasting sex bias in Neolithic and Bronze Age Eurasian migrations. In: Proceedings of the National Academy of Sciences. P. 2657-2662.

Haak A. et al. 2015. Massive migration from the steppe was a source for Indo-European languages in Europe. In: Nature. No. 522. P. 1-32.

Klejn L. S. 2017. Discussion: Are the Origins of Indo-European Languages Explained by the Migration of the Yamnaya Culture to the West? In: European Journal of Archaeology. No. 1. P. 1-15.

Kristiensen K. et al. 2018. Trade and civilisation: economic networks and cultural ties, from prehistory to the early modern era. Cambrige University Press.

Lazaridis I., Reich D. 2017. Failure to replicate a genetic signal for sex bias in the steppe migration into Central Europe. In: Proceedings of the National Academy of Sciences, No. 114 (20). P. 38733874.

Motuzaite Matuzeviciute G. 2012. The earliest appearance of domesticated plant species and their origins on the western fringes of the Eurasian steppe. In: Documenta Praehistorica. No. XXXIX. P. $1-21$. 
Motuzaite Matuzeviciute G. et al. 2016. Climatic or dietary change? Stable isotope analysis of Neolithic-Bronze Age populations from the Upper Ob and Tobol River basins. In: The Holocene. P. 1711-1721.

Mühlemann B. et al. 2018. Ancient hepatitis B viruses from the Bronze Age to the Medieval period. In: Nature. No. 557 (7705), 17 may 2018. P. 418-423.

Ollivier M., Tresset A. et al. 2018. Dogs accompanied humans during the Neolithic expansion into Europe. In: Biology Letters by Royal Society. No. 17, October 2018. pii: 20180286. doi: 10.1098/ rsbl.2018.0286.

Outram A. K. 2014. The Oxford Handbook of the Archaeology and Anthropology of Hunter-Gatherers. Oxford.

\title{
“GENETIC REVOLUTION” IN LIGHT OF TOPICAL PROBLEMS OF THE HISTORY OF NORTHERN EURASIA IN THE PALEOMETAL EPOCH
}

\author{
Viktor A. Novozhenov \\ UNESCO Center for the Raprochement of Cultures, Almaty, Kazakhstan
}

Keywords: migrations, Eurasian steppes, Pit-Grave (Yamnaya) culture, Catacomb communities, Chemurchek migration, domestication of horse, Botay culture, Sintashta culture, Paleometal Age.

The report is a historiographic review of the main concepts on the topic and is devoted to the period of globalization in the Eurasian steppe in the Paleometal Age - the period of formation and domination of elite clans of the Eneolithic and Early Bronze Age societies in Central Asia. Based on the analysis of DNA and visual art sources, the author substantiates a model of interactions between the populations in Turkestan and Central Asia. On the basis of the well-known innovations of horse equipment, means of transport and successes in domestication of horse, the main vectors of communications of the population and general trends in the development of the ethnocultural situation in this period are considered. The author believes that the extensive migration of Western European livestock producers to the East, proved on the basis of population genetics, archeology, analysis of pictorial monuments and linguistics, led to significant changes in the material and spiritual culture of local societies, determined cultural genesis in the region and progress in their own development.

\section{ОЧАГОВО-АККУМУЛЯТИВНАЯ КОНЦЕПЦИЯ КУЛЬТУРОГЕНЕЗА}

\author{
В. Б. Панковский \\ Институт археологии НАН Украины, Киев, Украина
}

DOI: 10.31600/978-5-907053-35-9-15-18

Ключевые слова: Восточная Европа, бронзовый век, культурогенез, очагово-пульсачионная концепция, очагово-аккумулятивная концепция, металлопроизводственная периодизация.

Влияние очагово-пульсационной концепции культурогенеза (Бочкарёв 1991; 1995; 2013; 2015) обычно усматривается в ее региональных прочтениях, утверждающих преемственное следование исходным идеям. Между тем в преисторическом дискурсе недавно распознана очагово-аккумулятивная кониепция культурогенеза (Pankowski 2019). Порой она самоопределялась как переложение очагово-пульсационной концепции, оперировала ее терминами и постулатами (Отрощенко 1996), а порой нарочито дистанцировалась, позиционируя себя через неприятие и отрицание (Пряхин 1996). Эту концепцию, вобравшую особые взгляды на культурообразование и стоящую на собственных теоретико-методических основаниях, нельзя считать дериватом очагово-пульсационных воззрений; но она прямо инспирирована ими. 